\title{
Cost optimal energy performance renovation measures in a municipal service building in a cold climate
}

\author{
Juha Jokisalo $^{1 *}$, Paula Sankelo ${ }^{2}$, Juha Vinha ${ }^{3}$, Kai Sirén ${ }^{1}$ and Risto Kosonen ${ }^{1,4}$ \\ ${ }^{1}$ Department of Mechanical Engineering, Aalto University, Espoo, Finland \\ ${ }^{2}$ Finnish Environment Institute, Helsinki, Finland \\ ${ }^{3}$ Department of Civil Engineering, Tampere University of Technology, Tampere, Finland \\ ${ }^{4}$ College of Urban Construction, Nanjing Tech University, Nanjing, P.R. China
}

\begin{abstract}
The energy saving potential of existing buildings is significant compared to new buildings in the EU region. To reduce significantly the $\mathrm{CO}_{2}$ emissions of buildings, energy efficiency of old buildings need to be improved. Aim of this study is to determine cost-optimal solutions for energy renovation and renewable energy production systems for an old existing service building. The example building of this study is a residence for elderly people, which was built in 1955 and located in Finland. This study was carried out by a dynamic building simulation tool IDA-ICE and multi objective optimization tool MOBO. The cost-optimal renovation concepts were determined from over 2.6 billion renovation measure combinations to minimize both target energy consumption and life-cycle costs over 20 years. The results show that air-to-water heat pump is more cost effective heating system for the studied building than district heating from the building owner point of view. Improving thermal insulation level of the external walls from the original level is not the most cost-effective option to improve the energy efficiency of the building. Instead of that, for example, installation of PV and solar thermal systems are recommended in all the cost-optimal solutions regardless of the target energy consumption level.
\end{abstract}

\section{Introduction}

The European commission presented its strategic longterm vision for net-zero greenhouse gas emissions by 2050 [1]. The building sector is one of the largest energy consumers in the EU area [2] and the energy saving potential of existing buildings is significant compared to new buildings. The current building refurbishment rate within the EU is rather low $0.5-1.2 \%$ in a year, depending on the region [3]. This refurbishment rate includes all refurbishments, even those that do not include energysaving measures.

To achieve the net-zero emission level by 2050 energy efficiency of existing buildings needs to be improved significantly. This underlines the pressure of increasing the refurbishment rate and the need of costoptimal energy performance renovation measures for existing buildings.

Aim of this study is to determine cost-optimal solutions for energy renovation and renewable energy production systems for old existing service buildings located in Finnish cold climate. Multi-objective optimization was utilized to minimize both energy consumption and life cycle cost.

\section{Methods}

\subsection{Example building}

The example building of this study, called Jukola building, is a residence for elderly people (see Figure 1). Jukola is located in Southern Finland (Tampere), it was originally built in 1955 and renovated between 2011 and 2013. Jukola has a brick exterior finished with plastering, 5 floors and a heated net floor area of $4709 \mathrm{~m}^{2}$.

It was assumed that Jukola is still in a state of prerenovation, whereby it represents old non-renovated service buildings. According to that assumption, there were for example a mechanical exhaust ventilation system without heat recovery, poorly insulated external walls and 2-pane windows with U-values 0.7 and $2.9 \mathrm{~W} / \mathrm{m}^{2}, \mathrm{~K}$. However, a ventilation rate was assumed to be the same as the current post-renovation level.

\subsection{Dynamic simulation and optimization}

The study was carried out using a simulation-based optimization. The example building and the building service systems were simulated with dynamic simulation tool IDA-ICE [4]. The multi-objective optimization tool MOBO was combined with IDA-ICE and the optimizations were carried out with the genetic NSGA-II algorithm $[5,6]$. The test reference year (TRY2012) of the

\footnotetext{
* Corresponding author: juha.jokisalo@,aalto.fi
} 


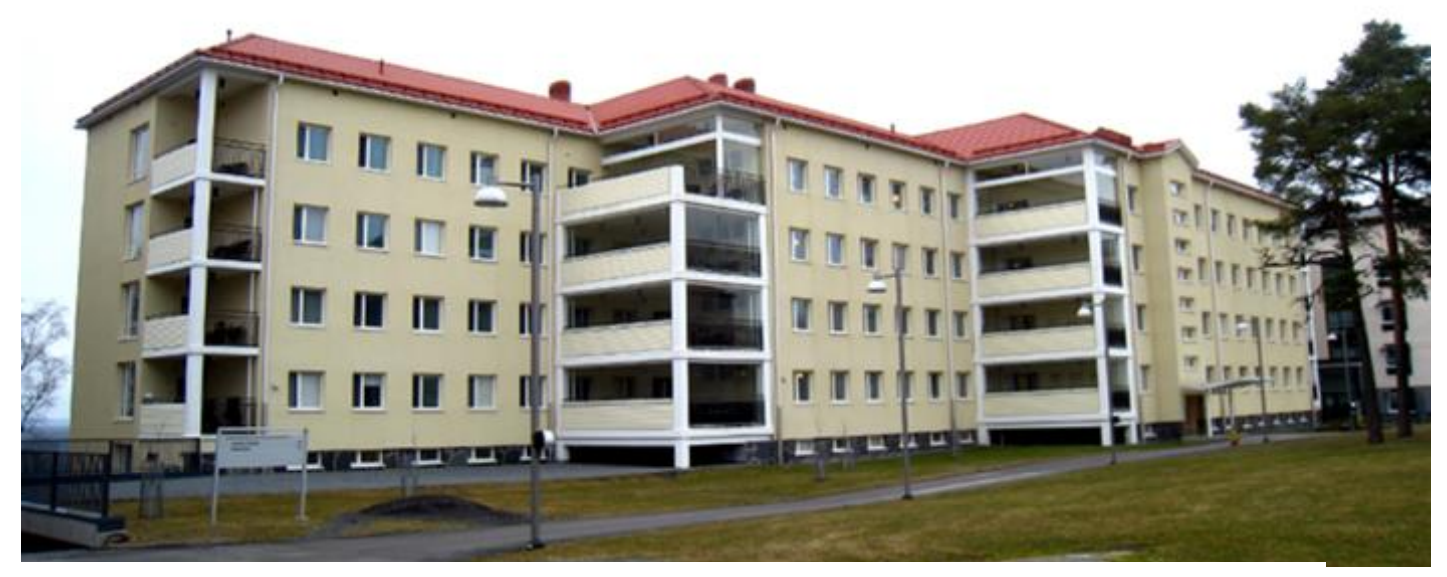

Figure 1. Jukola building in Koukkuniemi old people's home. Photo: Paula Sankelo

Finnish climatic zones (I-II) describing the current climatic conditions of Southern Finland was used in the study [7].

Simulation-based optimization was used to find cost-optimal solutions by minimizing target energy consumption of the building and lifecycle cost of the studied options.

\subsection{Target energy consumption}

Target energy consumption $\left(\mathrm{kWh} / \mathrm{m}^{2}\right.$, a) was defined as the sum of the annual purchased energy consumption of heating, cooling, ventilation, lighting and room appliances and HVAC auxiliary systems, i.e. total annual purchased energy consumption of the building simulated with the actual usage of the building and divided by the heated net floor area of the building.

Used occupancy and usage profiles of lighting and equipment as well as a measured domestic hot water consumption profile are defined in [8].

\subsection{Life-cycle cost}

The net present value life cycle cost (LCC) of the studied options was determined over a period of 20 years. LCC included investment costs, maintenance costs, replacement costs, residual value after 20 years, energy import costs and profit from selling the excess solar electricity. Discounting was done by using a real interest rate of $3 \%$ and energy price escalation rate of $2 \%$.

Fixed prices of district heat $(0.052 € / \mathrm{kWh})$ and electricity including transfer fee $(0.081 € / \mathrm{kWh})$ were used and a feed-in tariff of solar electricity was $0.028 € / \mathrm{kWh}$.

\section{Studied solutions for energy renovation and renewable energy production}

Cost-optimal solutions for Jukola building were individually optimized for two alternative heating solutions, including an air-to-water heat pump with electric auxiliary heating and district heating.
An air-to-water heat pump was selected for this optimization study, as the previous study [8] showed that it is a cost-optimal heating solution in the studied building. COP of the studied heat pump was 3.7 at the rating conditions $\left(7 / 45^{\circ} \mathrm{C}\right)$ [9]. In the optimization study, the cost-optimal dimensioning of the air-to-water heat pump was also determined allowing the heat pump capacity to vary from 1 to $202 \mathrm{~kW}$. The maximum heating power demand of space heating and ventilation is $216 \mathrm{~kW}$ in the studied building, so the maximum allowed power dimensioning of the heat pump corresponds to $94 \%$ share of the maximum power demand.

Since temperature level of heat distribution system has significant effect on the COP of the heat pump, it was assumed that the original radiators $\left(65 / 35{ }^{\circ} \mathrm{C}\right)$ were replaced with new low-temperature radiators $\left(45 / 35^{\circ} \mathrm{C}\right)$, when the heat pump system was installed. The costs of the new radiators were also taken into account in the study. It was also confirmed in the simulation, that temperature set point of space heating was reached in all the optimized cases even with the poorest thermal insulation level.

The district heating system was also included in the study because the Jukola building and most of the service buildings in Finland are practically heated by the district heating.

Table 1 shows the energy renovation measures and solutions for renewable energy production which were optimized for both of the heating systems, and thus selected as decision variables in the optimization cases.

Following energy renovation measures were optimized: improvement of thermal insulation level of external walls and roof, replacement of the original poorly insulated 2-pane windows with new energy efficient windows, replacement of the old mechanical exhaust ventilation system with mechanical supply and exhaust ventilation system with heat recovery, and installation of attendance, daylight and constant light control for the lighting of corridors and public living areas.

In the optimization, the renovation options for the external brick walls were a basic refurbishment without installation of additional thermal insulation, when the Uvalue remains unchanged $\left(0.7 \mathrm{~W} / \mathrm{m}^{2} \mathrm{~K}\right)$ or, in addition to the basic refurbishment, adding thermal insulation material by $50-200 \mathrm{~mm}$. In the case of the roof, 
Table 1. Decision variables for the optimization cases.

\begin{tabular}{|c|c|c|c|}
\hline Decision variables & Minimum investment & Maximum investment & $\begin{array}{l}\text { Type of the variable } \\
\text { and the studied } \\
\text { options }\end{array}$ \\
\hline $\begin{array}{l}\text { Renovation of } \\
\text { external walls }\end{array}$ & $\begin{array}{l}\text { Basic refurbishment } \\
\text { without installation of } \\
\text { additional thermal } \\
\text { insulation } \\
\text { (U-value } 0.7 \mathrm{~W} / \mathrm{m}^{2} \mathrm{~K} \text { ) }\end{array}$ & $\begin{array}{l}+200 \mathrm{~mm} \text { additional } \\
\text { thermal insulation } \\
\left(\mathrm{U} \text {-value } 0.17 \mathrm{~W} / \mathrm{m}^{2} \mathrm{~K}\right)\end{array}$ & $\begin{array}{c}\text { Discrete } \\
\text { (thickness of additional } \\
\text { thermal insulation: } 0 \\
+50,+100,+150 \text { or } \\
+200 \mathrm{~mm})\end{array}$ \\
\hline Renovation of roof & $\begin{array}{c}\text { No refurbishment } \\
\left.\text { (U-value } 1.22 \mathrm{~W} / \mathrm{m}^{2} \mathrm{~K}\right)\end{array}$ & $\begin{array}{l}+500 \mathrm{~mm} \text { additional } \\
\text { thermal insulation } \\
\left(\mathrm{U} \text {-value } 0.08 \mathrm{~W} / \mathrm{m}^{2}, \mathrm{~K}\right)\end{array}$ & $\begin{array}{c}\text { Discrete } \\
\text { (thickness of additional } \\
\text { thermal insulation: } 0, \\
+50,+100,+200,+300 \\
+400 \text { or }+500 \mathrm{~mm} \text { ) }\end{array}$ \\
\hline $\begin{array}{l}\text { Refurbishment of } \\
\text { original windows or } \\
\text { installation of new } \\
\text { windows }\end{array}$ & $\begin{array}{l}\text { Basic refurbishment of } \\
\text { original windows } \\
\left.\text { (U-value } 2.9 \mathrm{~W} / \mathrm{m}^{2} \mathrm{~K}\right)\end{array}$ & $\begin{array}{c}\text { Installation of new } \\
\text { windows, } \\
\left(\mathrm{U}-\text { value } 0.5 \mathrm{~W} / \mathrm{m}^{2} \mathrm{~K}\right)\end{array}$ & $\begin{array}{c}\text { Discrete } \\
\text { (U-value: } 2.9,1.0,0.9 \\
0.8,0.7,0.6 \text { or } 0.5 \\
\mathrm{~W} / \mathrm{m}^{2} \mathrm{~K}\end{array}$ \\
\hline $\begin{array}{l}\text { Design power of air- } \\
\text { to-water heat pump } \\
\text { (kW) (in the heat } \\
\text { pump case) }\end{array}$ & $\begin{array}{c}1 \\
(0.5 \% \text { of the max. power } \\
\text { demand })\end{array}$ & $\begin{array}{c}202 \\
\text { (94\% of the max. power } \\
\text { demand) }\end{array}$ & $\begin{array}{l}\text { Continuous, }(\min . \\
\text { change } 1 \mathrm{~kW})\end{array}$ \\
\hline Ventilation system & $\begin{array}{c}\text { Use of the old } \\
\text { mechanical exhaust } \\
\text { ventilation system (no } \\
\text { heat recovery) }\end{array}$ & $\begin{array}{c}\text { Installation of mechanical } \\
\text { supply and exhaust } \\
\text { ventilation system with } \\
\text { heat recovery } \\
\text { (temperature efficiency } \\
72 \% \text { ) }\end{array}$ & Discrete \\
\hline Control of lighting & No control & $\begin{array}{l}\text { Installation of occupancy, } \\
\text { daylight and constant } \\
\text { light control to corridors } \\
\text { and public living areas }\end{array}$ & $\begin{array}{c}\text { Discrete } \\
\text { (Control: No/Yes) }\end{array}$ \\
\hline PV-area $\left(\mathrm{m}^{2}\right)$ & 1.6 & 1000 & $\begin{array}{c}\text { Continuous } \\
\left(\mathrm{min} \text {. step } 1.6 \mathrm{~m}^{2}\right)\end{array}$ \\
\hline $\begin{array}{c}\text { Solar thermal } \\
\text { collector area }\left(\mathrm{m}^{2}\right)\end{array}$ & $0 / 6^{\mathrm{A}}$ & 120 & $\begin{array}{c}\text { Continuous } \\
\left(\text { min step } 6 \mathrm{~m}^{2}\right)\end{array}$ \\
\hline
\end{tabular}

A The minimum investment $0 \mathrm{~m}^{2}$ in the air-to-water heat pump case and $6 \mathrm{~m}^{2}$ in the case of district heating

the alternatives were just keeping the roof unchanged or adding thermal insulation material to the roof by $50-500$ $\mathrm{mm}$. Correspondingly, in the case of windows, studied options were a basic refurbishment of the original windows, when the U-value remains unchanged (2.9 $\mathrm{W} / \mathrm{m}^{2} \mathrm{~K}$ ) or installation of new windows with $\mathrm{U}$-value ranging from $0.5-1.0 \mathrm{~W} / \mathrm{m}^{2} \mathrm{~K}$.

To study the cost-optimality of the on-site renewable energy production, PV and solar thermal systems were studied. The studied systems were current off-the-shelf models, with price quotes readily available from the industry. The areas of the PV-panels and solar thermal collectors were allowed to vary from 1.6 to 1000 $\mathrm{m}^{2}$ and 0 to $120 \mathrm{~m}^{2}$.

The use of large-scale solar panel and collector areas were allowed in the study, although there is only about $200 \mathrm{~m}^{2}$ suitable area on the roof of the Jukola building to install PV panels or solar thermal collectors. If the installation of large PV panel or collector areas turns out to be profitable, they could also be installed elsewhere e.g. in the yard.

Alongside solar thermal collection, adequate thermal energy storage capacity is also needed. It was assumed in the study, that for every $6 \mathrm{~m}^{2}$ of solar thermal collector area, $0.3 \mathrm{~m}^{3}$ of installed hot water storage tank capacity is added. In the DH case, no previous storage tank exists, and the maximum tank volume installed was $6 \mathrm{~m}^{3}$, serving the maximum amount of solar thermal collectors. In the GSHP case, a $1.6 \mathrm{~m}^{3}$ tank was already in place, and it was enlargened up to $7.6 \mathrm{~m}^{3}$ as required.

\section{Results}

Figure 2 shows the lifecycle costs and the target energy consumption of all the optimized solutions for the Jukola building, which is heated by air-to-water heat pump or district heat. Pareto-optimal solutions presented in the figure determine cost optimal solution for both heating systems and each target energy consumption level. Figure 


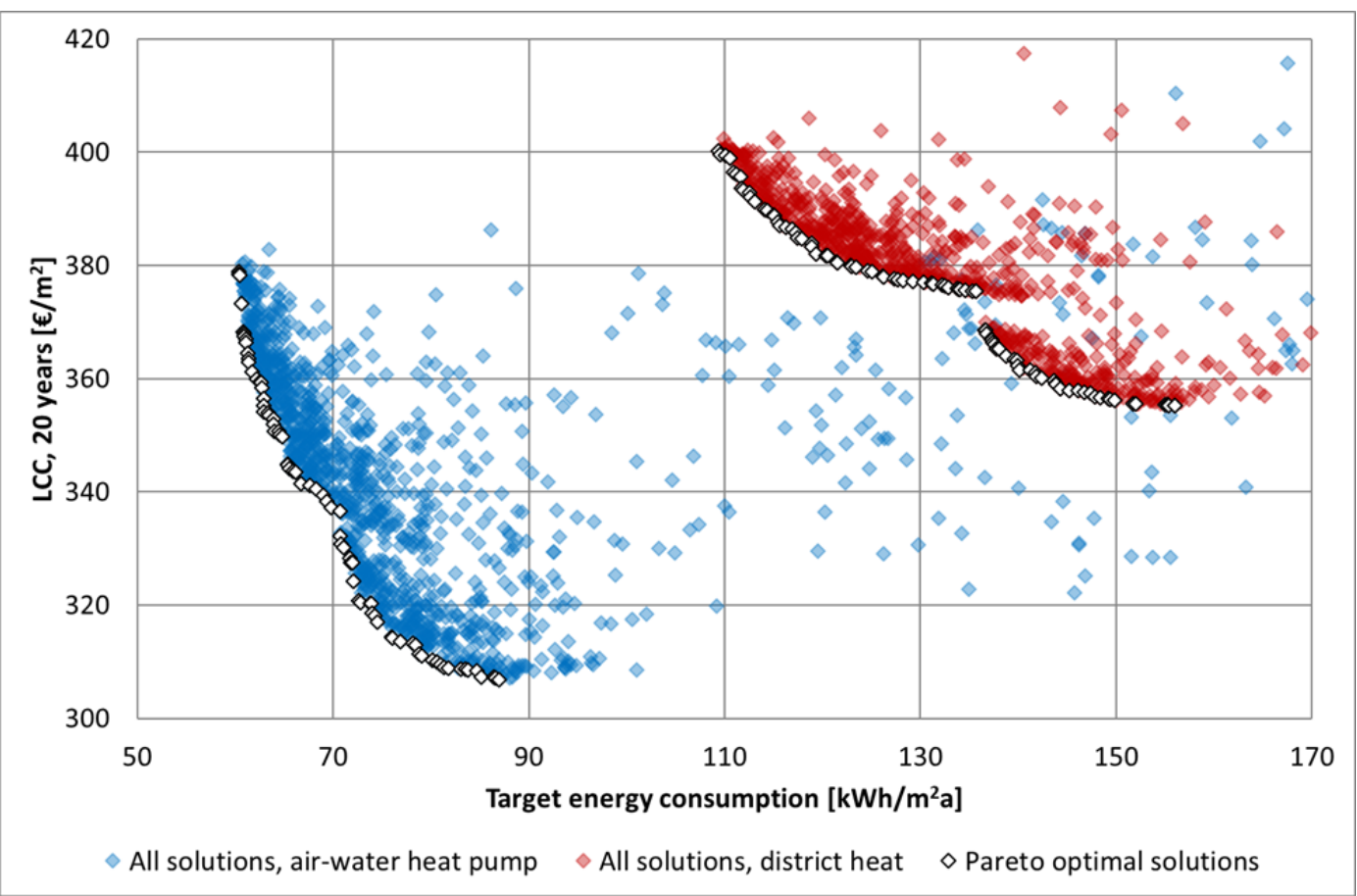

Figure 2. . Target energy use vs. life-cycle cost for Jukola building with either district heat or air-to-water heat pump. Pareto-optimal solutions for both main heating configurations are shown with white markers.

Table 2. The cost optimal solutions in the Jukola building, when air-to-water heat pump is the main heating system.

\begin{tabular}{|c|c|c|c|c|c|c|c|c|c|}
\hline $\begin{array}{l}\text { Target energy } \\
\text { consumption } \\
\left(\mathrm{kWh} / \mathbf{m}^{2} \mathbf{a}\right)\end{array}$ & $\begin{array}{l}\mathbf{L C C} \\
\left(€ / \mathbf{m}^{2}\right)\end{array}$ & $\begin{array}{l}\text { External } \\
\text { walls, } \\
\text { U-value } \\
\left(\mathbf{W} / \mathbf{m}^{2} \mathbf{K}\right)\end{array}$ & $\begin{array}{l}\text { Roof, } \\
\text { U-value } \\
\left(\mathbf{W} / \mathbf{m}^{2} \mathbf{K}\right)\end{array}$ & $\begin{array}{l}\text { Windows, } \\
\text { U-value } \\
\left(\mathbf{W} / \mathbf{m}^{2} \mathbf{K}\right)\end{array}$ & $\begin{array}{l}\text { Air-to- } \\
\text { water } \\
\text { HP } \\
\text { design } \\
\text { power } \\
(\mathrm{kW}) \\
\end{array}$ & $\begin{array}{l}\text { Efficiency } \\
\text { of } \\
\text { ventilation } \\
\text { heat } \\
\text { recovery }\end{array}$ & $\begin{array}{l}\text { Control } \\
\text { of } \\
\text { lighting }\end{array}$ & $\begin{array}{l}\text { PV- } \\
\text { area } \\
\left(\mathbf{m}^{2}\right)\end{array}$ & $\begin{array}{l}\text { ST- } \\
\text { area } \\
{\left[\mathbf{m}^{2}\right]}\end{array}$ \\
\hline \multicolumn{10}{|c|}{ Minimum LCC solution (global minimum) } \\
\hline 87 & 307 & 0.70 & 0.13 & 0.8 & $\begin{array}{c}101 \\
(47 \%)^{\mathrm{A}}\end{array}$ & 0.72 & Yes & 320 & 6 \\
\hline \multicolumn{10}{|c|}{ Minimum LCC solution for target energy use, when $\leq 80 \mathrm{kWh} / \mathrm{m}^{2} \mathrm{a}$} \\
\hline 80 & 310 & 0.70 & 0.10 & 0.5 & $\begin{array}{c}124 \\
(57 \%)^{\mathrm{A}}\end{array}$ & 0.72 & Yes & 492 & 8 \\
\hline \multicolumn{10}{|c|}{ Minimum LCC solution for target energy use, when $\leq 70 \mathrm{kWh} / \mathrm{m}^{2} \mathrm{a}$} \\
\hline 70 & 337 & 0.39 & 0.08 & 0.5 & $\begin{array}{c}99 \\
(45 \%)^{\mathrm{A}}\end{array}$ & 0.72 & Yes & 844 & 6 \\
\hline \multicolumn{10}{|c|}{ Minimum target energy use solution (also global minimum) } \\
\hline 60 & 379 & 0.17 & 0.08 & 0.5 & $\begin{array}{c}175 \\
(81 \%)^{\mathrm{A}}\end{array}$ & 0.72 & Yes & 993 & 118 \\
\hline
\end{tabular}

${ }^{\mathrm{A}}$ percentage of the maximum heat power demand of space heating and ventilation of the building

shows that the lowest LCC or target energy consumption level were reached with the air-to-water heat pump.

Tables 2 and 3 show pareto-optimal solutions for both of the heating systems at different target energy consumption levels, i.e. the tables show recommendable measures of the studied decision variables depending on the target energy consumption level.

Table 2 shows that the lowest life cycle cost (307 $€ / \mathrm{m}^{2}$ ) was achieved in the case where the air-to-water heat pump had a power output of $101 \mathrm{~kW}(47 \%$ of the maximum heat power demand of space heating and ventilation) and the basic refurbishment of the external walls was carried out without installation of additional thermal insulation and $300 \mathrm{~mm}$ additional thermal insulation was installed on the roof $\left(0.13 \mathrm{~W} / \mathrm{m}^{2} \mathrm{~K}\right)$. Also new windows $\left(0.8 \mathrm{~W} / \mathrm{m}^{2} \mathrm{~K}\right)$ and mechanical supply and exhaust ventilation system with heat recovery and lighting control were installed. The lowest LCC solution contained also $320 \mathrm{~m}^{2}$ of PV panels and $6 \mathrm{~m}^{2}$ of solar collectors.

Table 2 shows that if the building is heated with airto-water heat pump and the required target energy consumption level is about $70 \mathrm{kWh} / \mathrm{m}^{2}$, a or less, it is profitable to improve the thermal insulation level of the external walls from the original level. Instead of that, it is always profitable to improve the thermal insulation level of the roof, install new windows, ventilation system with heat recovery and control of lighting at all the studied target energy consumption levels. The results show that it 
Table 3. The cost optimal solutions in the Jukola building, when district heating is used.

\begin{tabular}{|c|c|c|c|c|c|c|c|c|c|}
\hline $\begin{array}{l}\text { Target energy } \\
\text { consumption } \\
\left(\mathbf{k W h} / \mathbf{m}^{2} \mathbf{a}\right)\end{array}$ & $\begin{array}{l}\mathbf{L C C} \\
\left(€ / \mathbf{m}^{2}\right)\end{array}$ & $\begin{array}{l}\text { External } \\
\text { walls, } \\
\text { U-value } \\
\left(\mathbf{W} / \mathbf{m}^{2} \mathbf{K}\right)\end{array}$ & $\begin{array}{l}\text { Roof, } \\
\text { U-value } \\
\left(\mathbf{W} / \mathbf{m}^{2} \mathbf{K}\right)\end{array}$ & $\begin{array}{l}\text { Windows, } \\
\text { U-value } \\
\left(\mathbf{W} / \mathbf{m}^{2} \mathbf{K}\right)\end{array}$ & $\begin{array}{l}\text { Efficiency } \\
\text { of } \\
\text { ventilation } \\
\text { heat } \\
\text { recovery } \\
(\%)\end{array}$ & $\begin{array}{l}\text { Control } \\
\text { of } \\
\text { lighting } \\
\text { (public } \\
\text { living } \\
\text { areas) }\end{array}$ & $\begin{array}{l}\text { Control } \\
\text { of } \\
\text { lighting } \\
\text { (corri- } \\
\text { dors) }\end{array}$ & $\begin{array}{l}\mathrm{PV}- \\
\text { area } \\
\left(\mathbf{m}^{2}\right)\end{array}$ & $\begin{array}{l}\text { ST- } \\
\text { area } \\
{\left[\mathrm{m}^{2}\right]}\end{array}$ \\
\hline \multicolumn{10}{|c|}{ Minimum LCC solution } \\
\hline 156 & 355 & 0.7 & 0.13 & 0.8 & 0.72 & Yes & Yes & 275 & 22 \\
\hline \multicolumn{10}{|c|}{ Minimum LCC solution for target energy use, when $\leq 150 \mathrm{kWh} / \mathrm{m}^{2} \mathrm{a}$} \\
\hline 150 & 356 & 0.7 & 0.08 & 0.8 & 0.72 & Yes & Yes & 274 & 64 \\
\hline \multicolumn{10}{|c|}{ Minimum LCC solution for target energy use, when $\leq 140 \mathrm{kWh} / \mathrm{m}^{2} \mathrm{a}$} \\
\hline 140 & 362 & 0.7 & 0.08 & 0.8 & 0.72 & No & Yes & 602 & 117 \\
\hline \multicolumn{10}{|c|}{ Minimum LCC solution for target energy use, when $\leq 130 \mathrm{kWh} / \mathrm{m}^{2} \mathrm{a}$} \\
\hline 130 & 377 & 0.39 & 0.1 & 0.8 & 0.72 & Yes & Yes & 368 & 89 \\
\hline \multicolumn{10}{|c|}{ Minimum LCC solution for target energy use, when $\leq 120 \mathrm{kWh} / \mathrm{m}^{2} \mathrm{a}$} \\
\hline 120 & 382 & 0.27 & 0.13 & 0.8 & 0.72 & Yes & Yes & 497 & 117 \\
\hline \multicolumn{10}{|c|}{ Minimum target energy use solution } \\
\hline 109 & 400 & 0.17 & 0.08 & 0.5 & 0.72 & Yes & Yes & 865 & 120 \\
\hline
\end{tabular}

is profitable to install a lot of PV panels even in the lowest LCC case, and if lower target energy levels are tried to achieve, a lot more PV panels are required. Installation of solar thermal collectors was also profitable in all the cases presented in Table 2.

Table 3 shows that if the building is heated with district heating and the required target energy consumption level is about $130 \mathrm{kWh} / \mathrm{m}^{2}$, a or less, it is profitable to improve the thermal insulation level of the external walls. As in the heat pump case, it is also profitable with district heating to improve the thermal insulation level of the roof, install new windows and ventilation system with heat recovery. But, it is not always profitable to install control of lighting in the public living areas. It is also profitable to install PV panels in the district heated building regardless of the level of target energy consumption, but less than in the heat pump case. In the district heating case, it is profitable to install solar thermal collectors more than in the heat pump case, but if the minimum target energy consumption levels are achieved, almost the maximum allowed solar thermal collector area was required with both of the heating method.

\section{Conclusions}

This study defined cost optimal energy renovation measures and solution of renewable energy production for the old municipal service building located in a cold climate in Finland.

In the studied building, the air-to-water heat pump with electric auxiliary heating was a more cost effective heating system than district heating. The improvement of thermal insulation level of the external walls was not the most cost-effective way to improve the energy efficiency of the studied building. Instead, preferred investments in all the cost-optimal solutions, regardless of the target energy consumption level, were:

- Installation of PV- and solar thermal systems.
- Improvement of thermal insulation level of the roof.

- $\quad$ Replacement of old windows with new energyefficient windows.

- Replacement of ole mechanical exhaust ventilation system with the mechanical supply and exhaust ventilation system with heat recovery.

- Installation of occupancy-, daylight- and constant light control.

In case the heating of the building was carried out with the air-to-water heat pump, the most reasonable way to further improve the energy efficiency from the level that corresponds to the lowest LCC, would be first to increase solar electricity production, then use more energyefficient windows and improve thermal insulation level of the roof.

Correspondingly, in the case of district heating, it would be reasonable to first increase solar thermal production and improve thermal insulation level of the roof and then increase the solar electricity production.

The study has received partial funding from European Regional Development Fund, as a part of Innovative Cities project of the Finnish Funding Agency for Innovation (Business Finland). Significant financing has also been granted from project partner companies.

\section{References}

1. European commission. A Clean Planet for all - A European strategic long term vision for a prosperous, modern, competitive and climate neutral economy. (2018) Available:

https://ec.europa.eu/clima/sites/clima/files/docs/page s/com_2018_733_en.pdf (accessed 3.2.2019)

2. The European Parliament and the Council of the European Union, "DIRECTIVE 2010/31/EU of the 
European Parliament and of the Council of 19 May 2010 on the energy performance of buildings", (2010).

3. Cubi, E., J. Ortiz, and J. Salom. Potential Impact Evaluation: An Ex ante Evaluation of the Mediterranean Buildings Energy Efficiency Strategy. International Journal of Sustainable Energy. (2014) doi:10.1080/14786451.2013.796945

4. P. Sahlin, Modelling and simulation methods for modular continuous system in buildings, $\mathrm{PhD}$ Thesis, Royal Institute of Technology (KTH), Stockholm, Sweden (1996)

5. http://ibpsa-nordic.org/tools.html (accessed 3.2.2019)

6. M. Palonen, M. Hamdy, A. Hasan, A. MOBO: $A$ new software for multi-objective building performance optimization. The proceedings of 13 th Conference of International Building Performance Simulation Association (2013)

7. T. Kalamees, K. Jylhä, H. Tietäväinen, J. Jokisalo, S. Ilomets, R. Hyvönen, S. Saku. Development of weighting factors for climate variables for selecting the energy reference year according to the EN ISO 15927-4 standard. Energy and Buildings, vol. 47, pp. 53-60 (2012).

8. J. Nyman, Cost optimal heating and cooling systems in nearly zero energy service buildings. MSc thesis. Aalto University, Espoo, Finland (2016) (Available: https://aaltodoc.aalto.fi/handle/123456789/20195)

9. Standard EN 14511-2:2013. Air Conditioners, Liquid Chilling Packages and Heat Pumps with Electrically Driven Compressors for Space Heating and Cooling. Part 2: Test Conditions, CEN European Committee for Standardization. (2013) 